$$
\text { ハードルフェンスによる }
$$

積雪寒冷地での環境林造成法

\author{
岡村俊邦*・吉井厚志**・東 三郎***・石岡二朗*
}

\title{
Wind-break and Snow-accumulation Effects of the Hurdle-fence for Afforestation of Environmental Conservation Forest
}

\author{
Okamura, Toshikuni*, Yoshil, Atsushi**, Higashi, Saburo***, IshiokA, Jiro* \\ 要旨
}

\begin{abstract}
地球環境問題への関心の高まりの中で，土木建設分野でも大規模な環境林造成事業が開 始されているが，植栽木の多くが気象害によって枯死するケースが目立っている。これは 対象地の多くが，堤防など強風にさらされることの多い広大なオープンスペースとなって いるためである。ハードルフェンスは，このような気象害を克服するために考案された防 風・堆雪栅であり, その特徵は, カラマツ間伐材を材料とし, 2 枚のパネルを合掌型に組 み合わせた安定した構造で, 透過性を持つことである。野外での防風・堆雪効果と植栽成 績に関する試験の結果, ハードルフェンスの設置区間の地表 $50 \mathrm{~cm}$ では $1 / 5$ 程度に風速が低 下すること, これにともなって, 降雪の初期にはいち早く堆雪し, 融雪の後期には, より 遅くまで残雪があることが確認できた。また，ハードルフェンスの設置区間では，植栽木 の高い活着率と旺盛な成長が見られた。これらのことは, ハードルフェンスの防風・堆雪 効果によって, 植栽木が晚秋および早春の乾いた寒風から保護されることによるものと推 定できた。
\end{abstract}

\section{1. はじめに}

地球環境問題への関心の高まりの中で，土木建設分野 でも緑の必要性が叫ばれ，大規模な環境林造成事業が開 始されている。一般に, 土木建設分野での環境林造成は, 造園や林業部門が主な対象地としてきた市街地の公園や 山間部と異なり, 河畔やダム, 道路, 空港, 港湾, ゴミ

キーワード：ハードルフェンス，樹林造成，環境林，防風，堆 雪

Key words: Hurdle-fence, Afforestation, Environmental Conservation Forest, Wind-break, Snow-accumulation

* 北海道工業大学

Department of Civil Engineering, Hokkaido Institute of Technology

** 北海道開発局開発土木研究所

Civil Engineering Research Institute, Hokkaido Department Bureau

****森林空間研究所

Institute of Silvan Space
の埋め立て地など，強風にさらされることの多い広大な オープンスペースとなっている。このため, 北海道のよ うな積雪寒冷地での環境林造成では, 晚秋から早春にか けての凍害 (霜害) ・寒風害, また, 晚春から初夏にかけ ての乾害などの強風に伴う気象害が大きな問題となる。

しかも，土木建設分野の環境林造成では，成木を植栽 する完成型の造成が多い。一般に植栽に用いられる成木 は, 経済効率が優先されるため, 環境条件の良いところ で環境圧から遮断して過保護に育てられたものが多い。 また，成木の場合，移植時に苗木に比べて根の切断がな される割合も高く,さらに，環境の変化に対する適応力 が小さい。このため, 大規模に実施されている環境林造 成事業の中には，気象害によって枯死するケースが目だ っている。

ハードルフェンスは，このような北国特有の気象害を 克服するために考案された，カラマツ間伐材を材料とし 
た透過型の防風・堆雪栅1,2) である。これは, 気象害の原 因となる寒風や乾風を弱め, また, 風速を落とすことに より, 植栽木を雪で覆い, 寒風が植栽木に直接当たるの を防ぎ，さらに，根系部の土裹凍結を防止することをね らったものである。本研究は, このハードルフェンスの 野外での防風・堆雪および土裹凍結防止の効果と, これ らの植栽木の生育への影響を明らかにしょうとしたもの である。

\section{2. ハードルフェンスの構造と樹木の植栽方法}

2.1 ハードルフェンスの構造

図 1 に 1 セット（基）のハードルフェンスの構造を示 した。図に示すように，ハードルフェンスは, カラマツ 間伐材で造られた 2 枚の透過性パネルを，側面が正三角 形となるように合掌型に組み合わせたものである。

北海道では, 第二次世界大戦後に大面積に植栽された カラマツ林が間伐期を迎えており，間伐の促進をはかる 必要があるが, 間伐材の材価が低いために間伐が進まず, 森林の荒廃が危惧されている。そこで, カラマツ間伐材 を使ったハードルフェンスの開発によって, 間伐の促進 をはかり, 森林を活性化すると同時に, 土木建設事業に ともなう荒廃地での森林の再生をはかろうとした。

また, 透過性パネルの防風効果については, 現在のと ころ, 純理論的には解かれていないが，風波の制御を目 的とした風洞実験では, その有効性が認められており, 空隙率 $50 \%$ が最も有効とされている ${ }^{3)}$ 。風波の場合, 水面 付近での防風効果が問題となるが, 苗木に対しても地表 付近の防風効果が重要であり, 風波と同様に考えられる。 さらに, 景観上, 自然環境に馴染みやすい木製の栅は, 地表付近が腐朽しやすい。このため，1枚のパネルを垂 直に立てるタイプのものは, 接地部付近の腐朽によって, 植栽木が十分生育する前に倒壊することが多い。しかし，
ハードルフェンスは, 合掌型の構造であるため, 地表付 近の接地部が腐朽しても倒壊することがない安定した構 造となっている。また，ハードルフェンスは，2枚のパ ネルでつくる三角柱が 1 単位となり, 自由な配置が可能 である。さらに, 数人の人力で容易に配置を変更するこ とも可能である。

ハードルフェンスの野外での設置では, 現在までにつ ぎの 3 つのタイプの配置を試みた（図 2 )。

a) 枡 (スクウェアー) タイプ

このタイプの標準配置は, 図 2 の(a)に示したように, 1 辺に 3 基のハードルフェンスを使用し, 基盤の目状に 配列したものである。植栽用の畧は, ハードルフェンス に囲まれた各枡の中心部に小さい方形の畧を作り，これ を囲む形で 4 重の方形の畧を作っている。このタイプは, 細長い直線状の設置に向くことから, 道路や鉄道などべ ルト状の樹林の造成に適している。

このタイプの試験は, 小樽市の大浜海岸から南へ約 700 $\mathrm{m}$ の距離にある, 札幌市手稲区山口の廃棄物最終処理場 内に設けられた試験地で行った。ここは，かつて標高 2 〜 $3 \mathrm{~m}$ の農地であったが, ゴミの埋立によって周辺より 高くなり, 現在, 標高 $15 \mathrm{~m}$ 程度の小高い丘になっている。 このため, 石狩湾からの北風が直接吹き付ける強風地帯 となっている。ここでは, 1990年11月（枡タイプ1）お よび1991年11月（枡タイプ2）に試験地が設けられてい る。

b) 蜂の巣 (ハニーカム) タイプ

このタイプの標準配置は, 図 2 の(b)に示したように 1 辺 2 基のハードルフェンスで構成する 6 角形を多数組み 合わせたものである。枰型と同様にハードルフェンスに 囲まれた各 6 角形の中心部に小さい 6 角形の畧を作り, これを囲む形で 4 重の 6 角形の畧が作られている。この タイプは, 1 辺 2 基のハードルフェンスを使用した基本

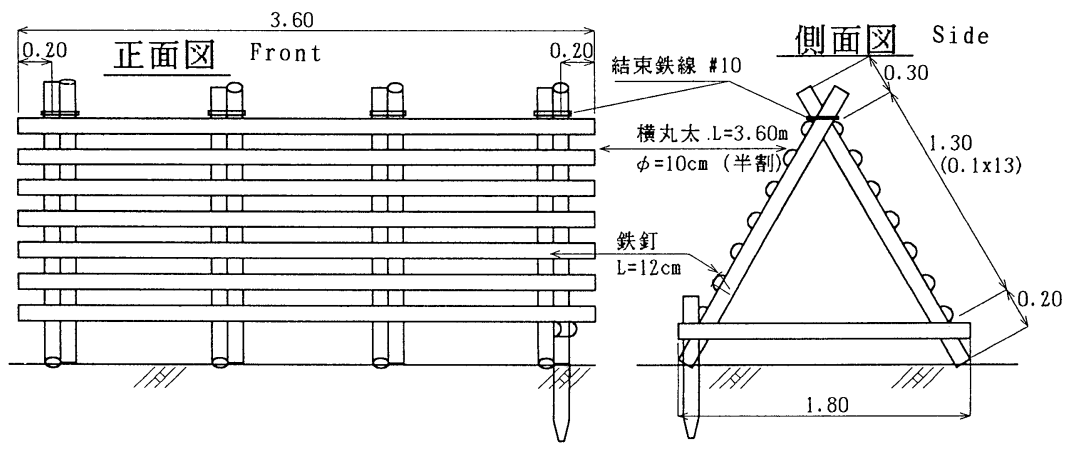

図 1 ハードルフェンス

Fig. 1 Hurdle-fence 


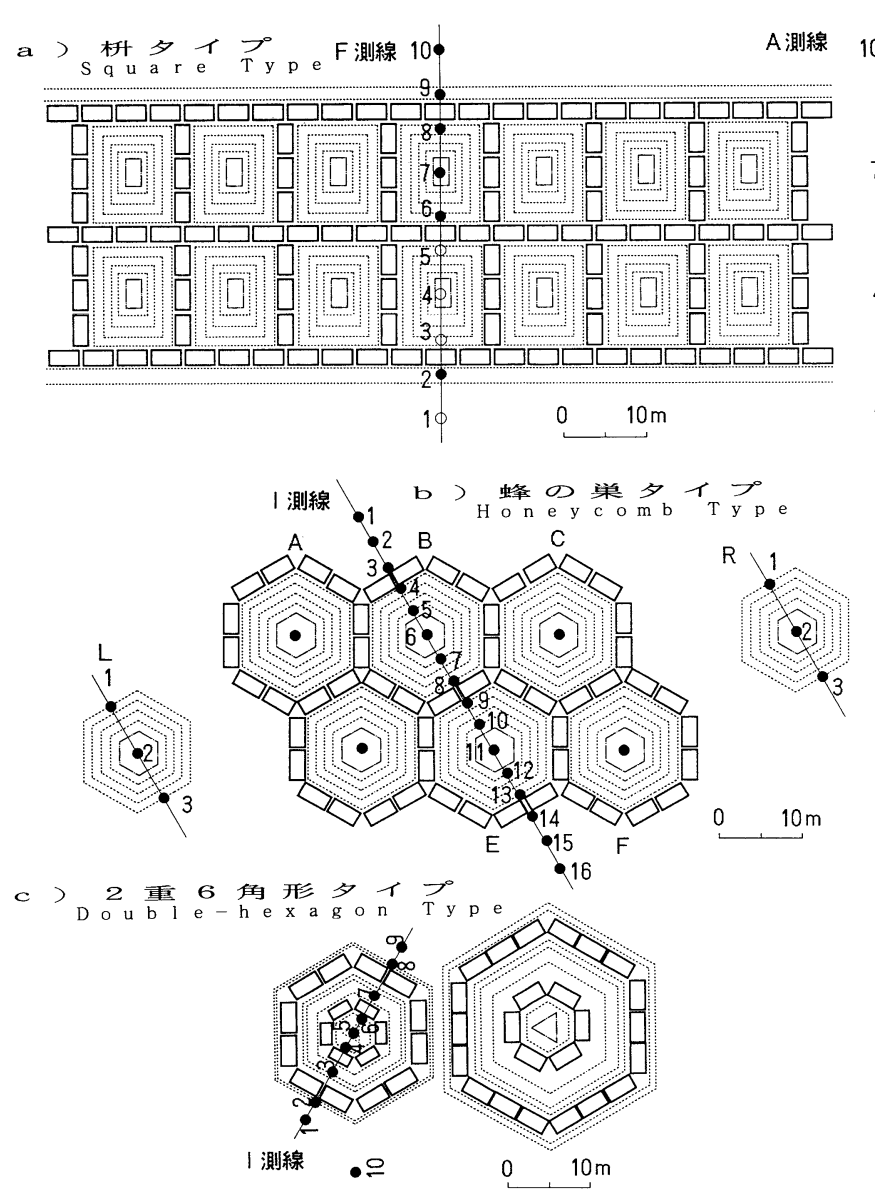

図 2 ハードルフェンスの配置例と気象観測点
$\square$ : ハードルフェンス, 観測点 $($ 風速・積雪深・凍結深)
: 畧施工位置 (基本林),
: 嘼施工位置
$\bigcirc$ : 観測点 (風速・積雪深・凍結深), 観測点 (風速・積雪深)

Fig. 2 Arrangements of Hurdle-fences and observation lines of micrometeological phenomena

の 6 角形をつなぐことにより,複雑な平面形に対応でき, また，景観的にも枡型タイプよりソフトな印象を与える ことから，公園の緑地造成に適している。

このタイプの試験も，先に述べた札幌市手稲区山口の 廃棄物最終処理場内に，枡（スクウェアー）タイプと隣 接して，1992年の11月に設けられたものである。

c ） 2 重 6 角形（ダブルヘキサゴン）タイプ

このタイプは, 現在, 2つのパターンが使われている (図 2 の(c))。1つは, 1 辺 3 基のハードルフェンスを使 用した 6 角形の内部に， 1 辺 1 基の小型のハードルフェ ンスを使用した 6 角形を設置したものである。もう 1 つ は, 外側の 6 角形に 1 辺 2 基のハードルフェンスを使用 したもので, 内側の 6 角形は同じである。このタイプは, 面的な樹林ではなく, 丘陵堤や大型の都市公園など広大
な敷地を対象に，スポット的な緑の拠点（ビオトープ） を作るのに適している。

このタイプの試験は, 石狩川の河口に近い石狩川左岸 の生振築堤の堤内地側で実施した。試験地を設定した堤 防は, 5 割勾配の丘陵堤となっており, 約 $2 \mathrm{~km}$ の間に 12 基の 2 重 6 角形（ダブルヘキサゴン）タイプが設置され ている。ここも, 石狩湾に近く, かつ, 広大なオープン スペースとなっているため, 海からの潮風が吹き付ける 強風地帯となっている。試験地としたところは, 最も下 流に位置するもので，1992年10月に設置されたものであ る。

\section{2 使用樹種と苗木の植栽方法}

植栽樹種は在来種から選ばれており, 前生林となる先 駆性の樹種と, 基本林となる持続性の樹種からなってい 
表 1 植栽樹種一覧

Table 1 Lists of planting trees

\begin{tabular}{|c|c|c|c|c|}
\hline タイプ & 植栽年 & 樹種 & 本数 (本) & 備考 \\
\hline \multirow[t]{9}{*}{ 枰タイプ 1} & 1990 & $\begin{array}{l}\text { オノエヤナギ } \\
\text { Salix sachalinensis }\end{array}$ & 7,304 & 挿し木 \\
\hline & & $\begin{array}{l}\text { ケヤマハンノキ } \\
\text { Alnus hirsuta }\end{array}$ & 972 & \\
\hline & & $\begin{array}{l}\text { ドロノキ } \\
\text { Populus maximowizii }\end{array}$ & 36 & 埋枝 \\
\hline & & $\begin{array}{l}\text { トドマツ } \\
\text { Abies sachalinensis }\end{array}$ & 108 & 3 本束植え \\
\hline & & $\begin{array}{l}\text { アカエゾマツ } \\
\text { Pisea glehnii }\end{array}$ & 36 & \\
\hline & & $\begin{array}{l}\text { イタヤカエデ } \\
\text { Acer mono }\end{array}$ & 36 & \\
\hline & & $\begin{array}{l}\text { ミズナラ } \\
\text { Quercus mongolica var. grosseserrata }\end{array}$ & 36 & \\
\hline & & $\begin{array}{l}\text { カシワ } \\
\text { Quercus dentata }\end{array}$ & 36 & \\
\hline & & $\begin{array}{l}\text { ハルニレ } \\
\text { Ulmus davidiana var. japonica }\end{array}$ & 36 & \\
\hline \multirow[t]{3}{*}{ 柝タイプ 2} & 1991 & $\begin{array}{l}\text { オノエヤナギ } \\
\text { Salix sachalinensis }\end{array}$ & 4,392 & 插し木 \\
\hline & & $\begin{array}{l}\text { ケヤマハンノキ } \\
\text { Alnus hirsuta }\end{array}$ & 1,104 & \\
\hline & & 他の樹種は, 本数とも枡タイプ 1 と同様 & & \\
\hline \multirow[t]{8}{*}{ 蜂の巣タイプ } & 1992 & $\begin{array}{l}\text { オノエヤナギ } \\
\text { Salix sachalinensis }\end{array}$ & 2,688 & $\begin{array}{l}\text { 挿し木 } \\
\text { 対照区を含む }\end{array}$ \\
\hline & & $\begin{array}{l}\text { ケヤマハンノキ } \\
\text { Alnus hirsuta }\end{array}$ & 624 & 対照区を含む \\
\hline & & $\begin{array}{l}\text { ドロノキ } \\
\text { Populus maximowizii }\end{array}$ & 36 & 半数対照区 \\
\hline & & $\begin{array}{l}\text { トドマツ } \\
\text { Abies sachalinensis }\end{array}$ & 18 & \\
\hline & & $\begin{array}{l}\text { アカエゾマツ } \\
\text { Pisea glehnii }\end{array}$ & 18 & \\
\hline & & $\begin{array}{l}\text { ミズナラ } \\
\text { Quercus mongolica var. grosseserrata }\end{array}$ & 18 & \\
\hline & & $\begin{array}{l}\text { カシワ } \\
\text { Quercus dentata }\end{array}$ & 18 & \\
\hline & & $\begin{array}{l}\text { ハルニレ } \\
\text { Ulmus davidiana var. japonica }\end{array}$ & 36 & 半数対照区 \\
\hline 2 重 6 角形タイプ & 1992 & 植栽成績に言及しないため省略 & & \\
\hline
\end{tabular}

る。前生林とは, ヤナギ類やハンノキ類など有機物の乏 しい荒廃地でもよく成長するが比較的寿命が短い先駆性 の樹種からなり, 後述する基本林を保護するために造成 される樹林である。また, 基本林とは, 初期の成長は遅 いが比較的寿命が長く, 前生林の保護下で造成する樹林 である。

ハードルフェンス内の植栽にあたっては, 各夕イプと もハードルフェンスに囲まれた中心部の畧に, 基本林を 構成する樹種が18本ずつ（束植えのものを除く）植栽さ れている(表 1 )。将来の基本林は, この中心部の畎に植
えられた18本の苗木のうち，2，3 本が生き残ることに なり，これらが施工地に点在して樹林を構成することに なる。このため, 中心部の植栽樹種は, 将来の基本林の 全体の樹種配置を想定して，選択する必要がある。

各タイプとも, 中心部の畧を囲んで 4 重の畧が作られ ている。これらの畧は前生林のためのものであり, 外側 の 2 䇉は, ヤナギ類の埋枝工 (挿し木) が施工されてお り, 内側の 2 墒は, ケヤマハンノキの苗が植栽されてい る。ヤナギ類は, 有機物の乏しい荒廃地でも挿し木によ って容易に発芽・発根するため, 前生林の最前列の樹種 
に適している。また，ケヤマハンノキは，根瘤菌の働き により，有機物の乏しい荒廃地でもよく生育するため, ヤナギ類の埋枝工の内側に植栽し，基本林の保護の役割 を持たせている。なお， 2 重 6 角形(ダブルへキサゴン) タイプについては, 試験地が丘陵地となっているため, 堤体の掘削を伴う慾の施工を行わず，平坦な面に植栽を おこなった。

使用した苗木は，ハードルフェンスの防風・堆雪効果 を考えて,いずれも $50 \mathrm{~cm}$ 以下の小さいものとした。植栽 に当たっては, 各樹種とも斜め植えを行い, ハードルフ エンスの栅内を覆った雪の沈下に伴う幹折れを回避し た。また,トドマツ, アカエゾマツなどの針葉樹類は, 3 本を束にして植える束植えを実施し, 根の融合現象に よる環境圧への耐性の強化を期待した。さらに，ヤナギ 類の埋枝では, 斜め挿しを実施し, 凍結融解による抜け 上がりを防止した。施工時期はいずれも晚秋の11月であ る。

\section{3. 野外試験の方法}

\section{1 気象観測}

気象観測は，ハードルフェンスの野外での防風・堆雪 および土壌凍結防止の効果を明らかにするため, 風速, 堆雪深, 土壌凍結深を観測した。

\section{a ）風速観測}

各タイプともハードルフェンスの設置された試験地の 中心部を通り，晚秋および早春の季節風の主方向に平行 な観測線を設置した。そして，この線上のハードルフェ ンスの前後およびハードルフェンスとハードルフェンス の間に，ほぼ等間隔に観測点を設けた(図 2$)$ 。観測点の 高さは, 苗木への影響を考えて, 地上 $50 \mathrm{~cm}$ とした。また， 試験地内を通る観測線と平行に試験地外に対照測線を設 置し，両者の結果を比較した。

測定は，ビラム式風速計を複数用い，各観測点をほほ 同時に30秒間測定した。観測時期は，晚秋および早春の 季節風の強い日を選んで実施した。

b ) 堆雪深観測

堆雪深については，風速観測と同じ各観測点の位置に 測量用ポールを設置し,その位置での堆雪深を測定した。 測定は，1991年の12月から1992年の 4 月，および，1992 年の 12 月から 1993 年の 4 月まで 2 冬にわたって, 毎月 1 回実施した。また，各観測時とも，堆雪の上・中・下層 からスノーサンプラーで一定容積の雪を採取し, 重量を 計測して堆雪の平均密度を算定した。

c) 凍結深

凍結深は, 枰夕イプ 2 の試験地において, メチレンブ
ルー式凍土計をあらかじめ堆雪深の測定位置に挿入して 観測した。メチレンブルー式凍土計は，メチレンブルー で着色した水を透明なアクリルパイプに封入したもので ある。設置は, 長さ $1 \mathrm{~m}$ の塩化ビニールパイプを地中に 鉛直に挿入し,その内側に同じ長さの凍土計を挿入した。 そして, 凍結によって色調の変化した部分を凍結深とし た。

なお,メチレンブルー式凍土計の数が限られていたた め, 冬季の季節風が当たる北側を中心に 4 箇所の観測点 を設けた。

\section{2 植栽成績}

植栽成績の調査は, 各試験地とも，ハードルフェンス に囲まれた析ごとに実施した。調査項目は，活着率と樹 高および当年成長量とした。植栽時期が秋のため, 活着 率は，すべての苗木および挿し穂（ヤナギ類）の翌春の 発芽の有無で判定した。また, 樹高および当年成長量は, 成長の停止した秋に，枡ごとに樹種別の優良木 5 本・標 準木 5 本を選定し測定した。なお，当年成長量とは，調 查した年の春から秋の 1 回の成長期間で成長した量を表 している。

\section{4. 試験結果}

\section{1 気象観測}

a) 風速

気像観測は，平成 2 年の 12 月から，最も早く設置され た枡タイプのもの ${ }^{3)}$ で開始されている。図 3 に, 柲夕イ プ, 蜂の巣タイプ， 2 重 6 角形タイプで観測された観測 結果を示す。これらは，それぞれの試験地において最も 風速の大きかった観測日の結果である。なお, 実線は試 験地の中央部を横断する測線（栅内）の, 破線は対照測 線とした試験地外の測線（栅外）で観測した地上 $50 \mathrm{~cm}$ に おける風速の分布である。

図 3 に見られるように, 各夕イプとも栅内で急激に風 速が低下していることがわかる。妌タイプでは，棚外の 風速が $5 \sim 6 \mathrm{~m} / \mathrm{s}$ であった時に, 栅内の地上 $50 \mathrm{~cm}$ の風速 は, 約 $1 \mathrm{~m} / \mathrm{s}$ と $1 / 5$ 程度に減速している。蜂の巣タイプで は, 図 2 に示したように, 試験地の両サイドに 2 本の対 照測線（L，R）を取ったため，栅外の風速として，2 本 の対照測線上の 6 箇所の観測点の平均風速を用いた。ま た, 2 重 6 角形タイプでは, 図 2 に示した栅外の 1 箇所 (10地点)の風速を栅外の風速として栅内と比較した。こ れらの観測值と栅内の観測值を比較すると, 2 重 6 角形 タイプでは, 枰タイプと同様, $1 / 5$ 程度の減速がみられる (図 3 )。また, 蜂の巣タイプでは, 栅外での $2 \sim 3 \mathrm{~m} / \mathrm{s}$ の 風速が栅内では $0 \sim 1 \mathrm{~m} / \mathrm{s}$ に減速している（図 3 ）。 

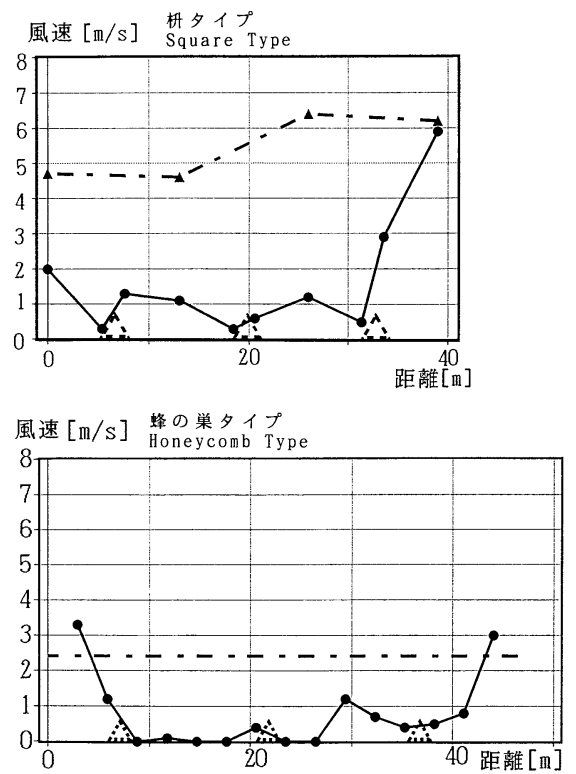

風速 $[\mathrm{m} / \mathrm{s}] \begin{gathered}2 \text { 重6 角形夕イプ } \\ \text { Double-hexagon Type }\end{gathered}$

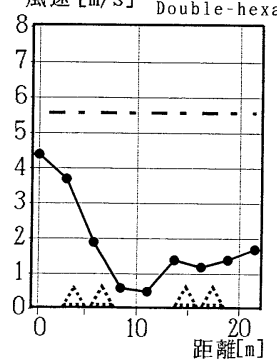

図 3

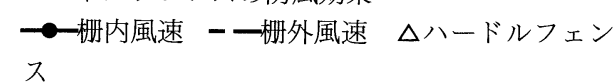

注）栅外の風速は，枡夕イプでは図 1 の $\mathrm{A}$ 測線の 実測值, 蜂の巣タイプでは $\mathrm{L}, \mathrm{R}$ の平均值, 2 重 6 角形タイプでは10地点の実測值で示した。

Fig. 3 Wind-break effect of the Hurdle-fence

\section{b ) 堆雪深}

図 4 は, 蜂の巣タイプで観測した堆雪深の推移とハー ドルフェンスの関係を示したものである。堆雪深の観測 は, 積雪期に月 1 回実施しており, 図には観測日ごとに, 各観測点での堆雪深の推移を示してある。堆雪深につい ては, 風速とは逆に, 棚内で急激に増加している。これ らのことは, 他の 2 タイプのものでも同様の結果となっ ている。

図 5 は, それぞれ栅内の堆雪深と栅外の積雪深および その水換算量を比較したものである。図のように, 各夕 イプともハードルフェンスの設置区間である栅内と対照

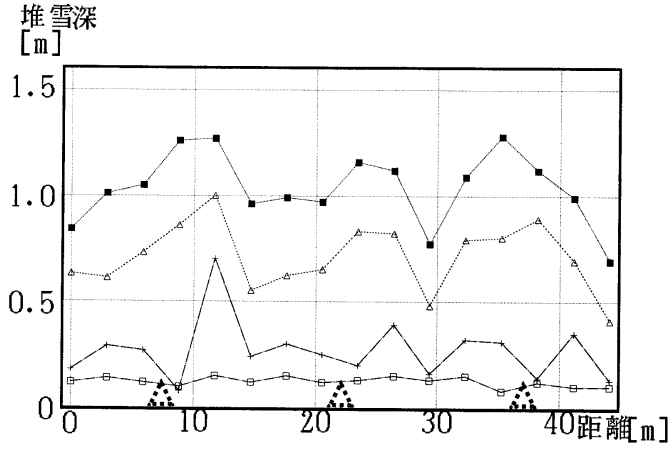

図 4 枅夕イプの堆雪深の推移

$\square$ '92.12. 4 +'93. 1.14

'93. $2.23 \triangle$ '93. 3.15

Fig. 4 Changes of snow-accumulation in Square Type

測線上の栅外では明瞭な差がみられる。この差は，ハー ドルフェンスの高さ $(1.6 \mathrm{~m})$ に積雪深が近づくと， 2 重 6 角形夕イプの 1993 年 2 月 23 日の観測值のように栅内と 栅外の差が減少する。

以上のことは, 降雪期の初期には, 降雪や地吹雪がハ ードルフェンスの防風効果によって, 栅内により多く堆 雪するが, 積雪の最盛期には, 栅外にも積雪が多くなり, 防風効果が小さくなり，棚内外の積雪深の差が小さくな ると考えられる。また, 積雪期の終わりごろには, 再び 防風効果が発揮され, 枡タイプや 2 重 6 角形タイプに見 られるように，栅外に比べてより遅くまで堆雪が残る結 果になると考えられる。

c) 凍結深

表 2 は, 枡夕イプでの試験地外と試験地内の観測点に おける凍結深の変化を示したものである。表に示したよ うに，降雪期のはじめに当たる1991年12月26日には，試 験地の内・外とも $2 \sim 3 \mathrm{~cm}$ の堆雪深しかなく，この時の 凍結深は, この冬期の観測值として両者とも最高の 10 $\mathrm{cm}$ を記録した。その後, 堆雪深の増加とともに凍結深は 減少している。

\section{2 植栽成績}

植栽成績に関しては，1990年および1991年に施工され た枡タイプの試験地と1992年に施工された蜂の巣タイプ の試験地の結果が明らかとなっている。表 3 は, 枡夕イ プでの植栽 1 年後の樹種別の活着率を示している。活着 率は全体に良好であり，トドマツを除くとそれぞれ $60 \%$ 以上となっている。なお，ヤナギ類は，挿し木によって 導入されたものであるが, 活着率は $86.9 \%$ と高い值を示 

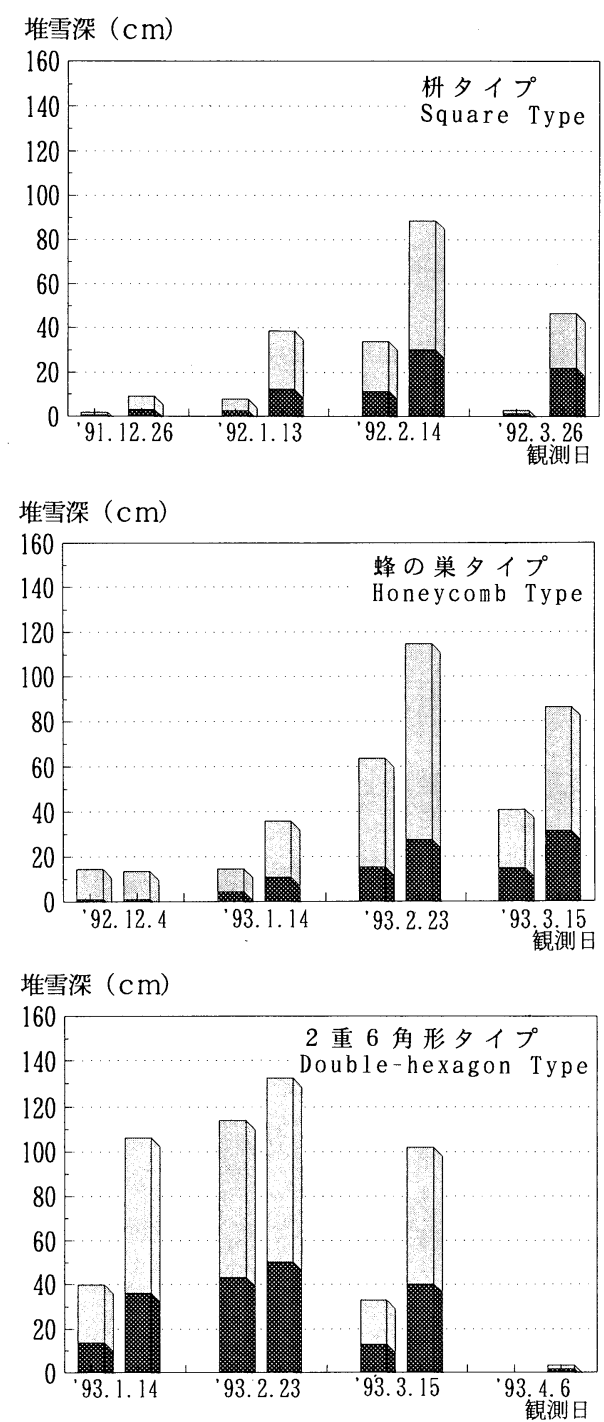

図 5 ハードルフェンスの堆雪効果の推移

注）各観測日とも左が栅外，右が栅内。

四角柱全体の高さが堆雪深, 濃いメッシュが水 換算量。

Fig. 5 Changes of snow-accumulation effects of the Hurdle-fence

している。

図 6 に1992年10月はじめの枡タイプの試験地での樹高 と当年成長量を示した。この図から前生林形成のために 導入された先駆性樹種であるドロノキ，ヤナギ類，ケヤ マハンノキが植栽後 2 年目に急激に成長したことがわか る。特に,ドロノキとヤナギ類の優良木では, 年に $1 \mathrm{~m}$ 以 上の成長が見られた。また，基本林の形成を目指して導
表 2 枡夕イプでの土壤凍結深の推移

Table 2 Change of soil-freezing depth

\begin{tabular}{cccccc}
\hline 観 測 日 & '91.12.10 & '91.12.26 & '92. 1.13 & '92. 2.14 \\
\hline \multicolumn{5}{c}{ 凍結深 } & $(\mathrm{cm})$ \\
観 & F1 & 8.0 & 10.0 & 3.5 & 0.0 \\
測 & F3 & 0.0 & 10.0 & 9.5 & 2.3 \\
点 & F4 & 10.0 & 8.0 & 5.5 & 0.0 \\
\hline
\end{tabular}

表 3 枅タイプでの 1 年後の活着率

Table 3 Root taking of planting trees in Square Type

\begin{tabular}{lrc}
\hline \multicolumn{1}{c}{ 樹重 } & 活着率(\%) & 備考 \\
\hline $\begin{array}{l}\text { ドロノキ } \\
\text { Populus maximowizii }\end{array}$ & 64.9 & 先駆性 \\
$\begin{array}{l}\text { ハルニレ } \\
\text { Ulmus davidiana var. japonica } \\
\text { カシワ }\end{array}$ & 80.6 & 持続性 \\
$\begin{array}{l}\text { Quercus dentata } \\
\text { ミズナラ }\end{array}$ & 94.4 & 持続性 \\
$\begin{array}{l}\text { Quercus mongolica var. grosseserrata } \\
\text { イタヤカエデ }\end{array}$ & 73.0 & 持続性 \\
$\begin{array}{l}\text { Acer mono } \\
\text { アカエゾマツ }\end{array}$ & 72.2 & 持続性 \\
$\begin{array}{l}\text { Pisea glehnii } \\
\text { トドマツ }\end{array}$ & 100.0 & 持続性 \\
$\begin{array}{l}\text { Abies sachalinensis } \\
\text { オノエヤナギ }\end{array}$ & 43.0 & 持続性 \\
$\begin{array}{l}\text { Salix sachalinensis } \\
\text { ケヤマハンノキ }\end{array}$ & 86.9 & 先駆性 \\
Alnus hirsuta & 69.7 & 先駆性 \\
\hline
\end{tabular}

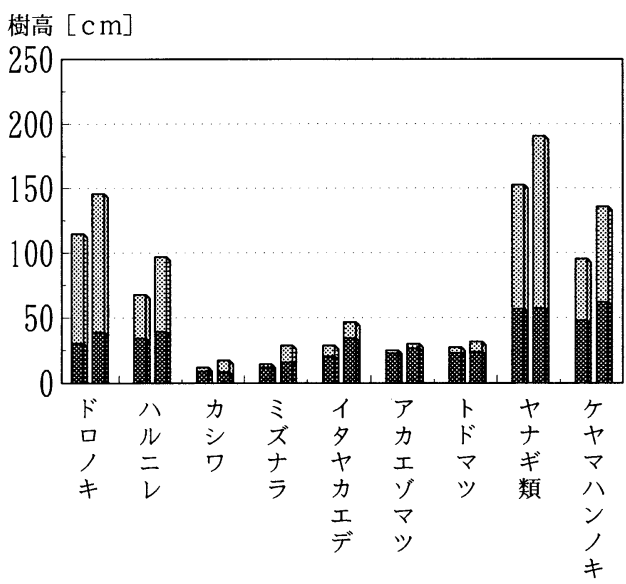

図 6 枡タイプの植栽木の樹高と当年成長量

注）各樹種とも左が標準木，右が優良木。 四角柱全体の高さが樹高, 薄い部分が当年成長 量。

Fig. 6 Height and growth of planting trees in Square Type 

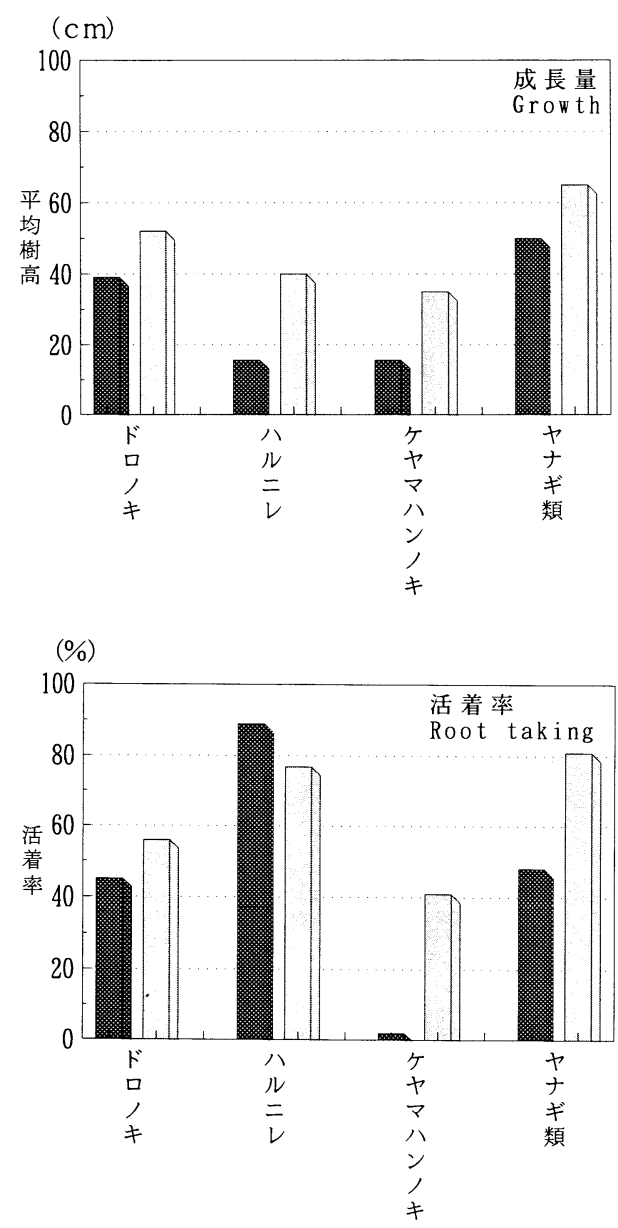

図 7 蜂の巣タイプでの成長量と活着率

注）各樹種とも左が柱外，右が棶内。

Fig. 7 Growth and root taking of planting trees in Honeycomb Type

入された持続性樹種も, 先駆性樹種の保護下で順調な生 育を示している。なお，この図では，持続性樹種の当年 成長量が低いように見えるが, 当年成長量以外の部分は 苗木の大きさを含んでおり, 植栽から 2 年目の段階では, 順調な成長と判断できる。

図 7 は，それぞれ蜂の巣タイプの試験地での植栽 1 年 後の平均樹高と活着率を栅外に設置した対照区との比較 で示したものである。今回, 試験地とした 3 箇所のうち, 植栽成績に関する対照区を設けたのは, 蜂の巣タイプだ けである。

平均樹高では, 植栽されている 4 種の樹種とも栅内の 成績が良好である。また, 活着率についても, ハルニレ を除くと，栅内の成績がよかった。また，ハルニレは栅
内外とも活着率が極めて高く，ハードルフェンスの有無 の影響は少ないと考えられる。一方, 活着率の最も低い ケヤマハンノキでは, ハードルフェンス有無の影響が最 も明瞭汇現れている。

一方, 蜂の巣タイプと先に述べた枅タイプでの栅内の 植栽成績を比較すると，成長量ではほほ同じ傾向を示す が，活着率では，異なる部分も見られた。すなわち，蜂 の巣タイプの 4 種の 1 年目平均樹高（図 7 ） は, 杵夕イ プの当年成長量を除いた標準木の樹高（図 6), つまり, 1 年目の樹高と, どの樹種もほほ一致している。一方, 活着率では, 両試験地の結果に大きな差はないが, ケヤ マハンノキでは $30 \%$ 近い差がみられた。

なお，先に述べたように，栅の内外でも，ケヤマハン ノキの活着率に大きな差が見られており，苗木の状態に 差があったことも考えられるが, 明確な原因は不明であ る。

\section{5. 結論}

広大なオープンスペースを対象とすることの多い土木 建設分野の環境林造成では, 寒冷ないし乾燥した強風と いう厳しい環境条件に対処するため，環境に対する適応 性の高い植物材料の選択と，厳しい環境圧の軽隇を図る ための資材の開発が必要である。本研究では，環境圧に 弱い成木を使用する完成型の造成を避け，小さな苗木や 挿し木および種子による導入にあたって，厳しい環境圧 の軽減を図るための資材としてのハードルフェンスの防 風・堆雪効果を明らかにしょうとした。

実験に使用した 3 タイプのハードルフェンスとも, 植 栽初期の幼木が存在する地上 $50 \mathrm{~cm}$ 付近において防風効 果が高く, また, 删内に初冬にいち早く堆雪し, かつ, 春には長く堆雪を残す効果を持つことが明らかとなっ た。また, この防風・堆雪効果は, 土裹凍結の防止でも 有効性が示唆された。このように, 樹木の生存にとって 最も危険な時期に, 寒風の減速と堆雪による保護がなさ れたことが，植栽木の旺盛な成長につながったものと考 えられる。

以上のように，ハードルフェンスの基本的な環境圧の 軽減の効果が明らかとなったことから, 今後は, 対象地 の特性を考慮したバリエーションを開発していく必要が ある。それによって, 生態系の再生および修景の観点か ら，今後ますます要望が高まると考えられる土木建設分 野の環境林造成において，大いに活用されると考えられ る。

最後に試験に際してご協力いただいた札幌市, 北海道 開発局の関係各位に深謝の意を表する。 


\section{引用文献}

1）東 三郎：環境林をつくる，北方林業会，pp. 205，1975

2）東 三郎：北海道 森と水の話, 増補改訂版, 北海道新 聞社, pp. 256, 1991

3）村木義男・大平正浩・竹内政夫・佐伯 浩：スリット型 防風栅の風波制御効果の予測に関する考際, 海洋開発論
文集8，307-312，1992

4）岡村俊邦・石岡二朗：環境林造成のためのハードルフェ ンスの防風・堆雪効果, 日本林学会北海道支部論文集41, 111-113, 1993

(1994.10.28受理)

\section{Summary}

Recently, many afforestation works have been carried out for environmental conservation in bare areas due to construction works. However, many planting trees have died of frost and drought damages in the cold district. Hurdle-fence is a slit-type fence devised for wind-break and snow-accumulation. Based on experiments, hurdle -fences can reduce the wind by one-fifth at $50 \mathrm{~cm}$ above the ground, and can keep accumulated snow longer (from early winter to early spring) inside of the fences compared to the outside. For these reasons, planting trees take root in higher rate and grow taller than those outside of the fences. 